\title{
Testosterone Secretion Inhibition
}

National Cancer Institute

\section{Source}

National Cancer Institute. Testosterone Secretion Inhibition. NCI Thesaurus. Code C41496.

Testosterone Secretion Inhibition consists of interference with, or restraint of, activities involved in release into the bloodstream by testicular interstitial (Leydig's) cells of the major androgenic steroid hormone (testosterone) produced in response to adenohypophyseal luteinizing hormone that regulates gonadotropic secretion; Wolffian duct differentiation into epididymis, vas deferens, and seminal vesicle; spermatogenesis after peripheral conversion to dihydrotestosterone by 5a-reductase; and skeletal muscle and bone tissue. Alteration of positive or negative feedback mechanisms can affect hormone release. 